\title{
STUDY ON THE SUGAR-ACID RATIO AND RELEVANT METABOLIZING ENZYME ACTIVITIES IN NAVEL ORANGE FRUITS FROM DIFFERENT ECO-REGIONS ${ }^{1}$
}

\author{
GONG RONGGAO ${ }^{2 *}$, YANG WEI ${ }^{4}$, WANG ZHIHUI ${ }^{2}$, LIAO MINGAN ${ }^{2}$, LIANG GUOLU ${ }^{3}$
}

ABSTRACT - The flavor quality of citrus fruits is largely determined by the sugar-acid ratio, but it remains uncertain how sugar- and/or acid-metabolizing enzymes regulate the sugar-acid ratio of navel oranges and further affect the fruit quality. In the present study, Robertson navel oranges (Citrus sinesis Osb.) were collected from six representative habitats in three eco-regions of Sichuan, China. The changes in the sugar-acid ratio and the activities of sucrose phosphate synthase (SPS), sucrose synthase (SS), cytosolic cio-aconitase (ACO), and isocitrate dehydrogenase (IDH) were examined in navel oranges during fruit development. The results indicated that the sugar-acid ratio of fruits in different eco-regions changed significantly from 150 days after full bloom. The SPS and cytosolic ACO fruit activities had minor changes among different ecoregions throughout the experimental periods, whereas the activities of SS and IDH changed significantly in fruits among three eco-regions. Furthermore, the sugar-acid ratio and the activities of SS in the synthetic direction and IDH were the highest in south subtropics and the lowest in north mid-subtropics, probably due to the effects of climate conditions and/or other relevant eco-factors. It demonstrated that SS in the synthetic direction and IDH were of greater importance in regulating the sugar-acid ratio of navel oranges in different eco-regions, which provided new insights into the factors that determine the flavor quality of navel oranges and valuable data for guiding relevant agricultural practices.

Index terms: navel orange, sugar-acid ratio, sucrose phosphate synthase, sucrose synthase, cytosolic aconitase, isocitrate dehydrogenase.

\section{ESTUDO SOBRE A RELAÇÃO AÇÚCAR-ÁCIDO E ATIVIDADES RELEVANTES METABOLIZADORAS DE ENZIMA EM FRUTOS DE LARANJA DE UMBIGO DE DIFERENTES ECOREGIÕES}

\begin{abstract}
RESUMO - A qualidade do sabor das frutas cítricas é amplamente determinada pela relação açúcar- ácido, mas permanece incerto como enzimas metabolizadoras de açúcar e / ou do ácido regulam a relação açúcarácido de laranjas de umbigo e depois afetarem a qualidade dos frutos. No presente estudo, laranjas de umbigo Robertson (Citrus sinensis Osb.) foram coletadas de seis habitats representativos em três ecorregiões do Sichuan, na China. As mudanças na relação açúcar-ácido e as atividades da síntese de sacarose fosfato (SPS), síntese de sacarose (SS), aconitase citossólica (ACO) e isocitrato desidrogenase (IDH) foram examinadas em laranjas de umbigo durante o desenvolvimento dos frutos. Os resultados indicaram que a relação açúcar-ácido de frutas em diferentes ecorregiões alterou significativamente a partir de 150 dias após a plena floração. O SPS e as atividades ACO citossólicas das frutas tiveram pequenas alterações entre diferentes ecorregiões ao longo dos períodos experimentais, enquanto que as atividades da SS e IDH alteraram significativamente em frutas entre três ecorregiões. Além disso, a relação açúcar-ácido e as atividades da SS na direção sintética e IDH foram as mais elevadas em regiões subtropicais sul e as mais baixas nas regiões do meio-subtropical norte, provavelmente devido aos efeitos das condições climáticas e / ou outros fatores-ecológicos. Demonstrou-se que a SS na direção sintética e IDH foram de maior importância na regulação da relação açúcar-ácido de laranjas de umbigo em diferentes ecorregiões, que forneceu novas descobertas sobre os fatores que determinam a qualidade do sabor das laranjas de umbigo e dados valiosos para orientar práticas agrícolas relevantes. Termos de indexação: laranja de umbigo, relação açúcar-ácido, síntese de sacarose fosfato, síntese de sacarose, aconitase citossólica, isocitrato desidrogenase.
\end{abstract}

${ }^{1}$ (Trabalho 210-15). Recebido em 21-07-2014. Aceito para publicação em: 12-05-2015. ${ }^{2}$ College of Horticulture, Sichuan Agricultural University, Ya'an City Sichuan 625000, China

${ }^{3}$ College of Horticulture and Landscape Architecture, Southwest University, Chongqing 400700, China

${ }^{4}$ Longquanyi District Fruit Research Institute, Chengdu City Sichuan 610000, China 


\section{INTRODUCTION}

Navel oranges are among the most common and popular citrus fruits due to their widespread distribution, long growing season, and rich flavor (SNYDER et al., 2011). Since navel oranges were introduced into China, great efforts have been made for decades in evaluating and improving the fruit quality of them (BAO et al., 2004; LIN, 2006; XIAO et al., 2006). The primary quality indicator of citrus fruits is the flavor quality, which is shown strongly correlated with the sweetness and acidities (KELEBEK and SELLI, 2011). The sweetness and acidities is largely determined by the type and quantity of sugars as well as associated organic acid content and the sugar-acid ratio of the fruit. Among them, the sugar-acid ratio reflects the relative contents of sugars and acids, thus is considered to be an important indicator for the flavor quality of citrus fruits (ALBERTINI et al., 2006).

The sugar-acid ratio of fruits is determined by sugar and acid metabolism through enzymatic reactions. Previous studies demonstrated that fruits contained a variety of sugar- and acid-metabolizing enzymes including soluble acid invertase, sucrose synthase (SS) in the synthetic or cleavage direction, sucrose phosphate synthase (SPS) (HASHIZUME et al., 2003; ZHANG et al., 2012; YANG et al., 2013), citrate synthase (CS), cis-aconitase (ACO), malate dehydrogenase, isocitrate dehydrogenase (IDH) and phosphoenolpyruvate carboxylase (PEPC) (KUBO et al., 2002; LUO, 2003). Among them, SPS and SS in the synthetic direction are closely related to sugar accumulation in fruits, whereas $\mathrm{CS}, \mathrm{ACO}, \mathrm{IDH}$, and PEPC are important enzymes that determine the organic acid content of citrus fruits. In our previous study, the sugar-acid ratio, SPS, SS, ACO, and IDH were found to play an important role in navel oranges at the developmental stages (GONG et al., 2008). Furthermore, the findings suggested that climate changes impacted on yield, carbon balance, partitioning and photosynthetic acclimation of fruits (LUEDELING et al., 2011; DARBYSHIRE et al., 2014; SALAZAR-PARRA et al., 2015). However, it remains uncertain how these key enzymes regulate the sugar-acid ratio of navel oranges in different eco-regions, and further influence the flavor quality of the fruit.

In China's vast areas, navel oranges are planted in large-scale orchards in different ecoregions. It has been noted that the flavor quality of navel oranges significantly varies in different orchards (eco-type areas), possibly due to the effects of habitat and/or eco-region on the sugar- and/or acid-metabolizing enzyme activities. In order to explore the underlying ecological and physiological mechanisms, this study investigated the changes in the sugar-acid ratio and relevant metabolizing enzyme activities of navel oranges in different habitats and eco-regions throughout the process of fruit development.

\section{MATERIALS AND METHODS}

\section{Study areas and plant materials}

This study was conducted in six representative eco-type areas (navel-orange orchards) in three ecoregions in Sichuan Province, China between February 2010 and December 2012. The orchards, including Hongge and Anning in a hot, dry south-subtropical eco-region, Changning and Jiang' an in a hot, humid mid-subtropical eco-region, and Mingshan and Ya'an in a humid north mid-subtropical eco-region with less sunshine hours, were chosen for analysis in accordance with fruit quality and relevant ecofactors, the detail information of these places were shown in Table 1. A map of the country with three eco-regions of Sichuan was doted in Figure 1.

The experimental plants were 10-year-old trees of navel orange (Citrus sinensis Osb. cv. Robertson) grafted on Satsuma mandarin (Citrus unshiu mark cv. Miyagawawase) rootstocks. From each orchard, five trees were randomly chosen as the samples and five medium-size fruits per sample tree were randomly taken in different directions (south, north, east, west, and top) each 15-day from days 60 to 225 after full bloom. The fruits were kept in an icebox to transport to the laboratory immediately after collection, and then stored at $-20^{\circ} \mathrm{C}$ prior to analysis.

\section{Sugar and acid extraction and determination}

The fruit samples were washed repeatedly with distilled water $\left(\mathrm{dH}_{2} \mathrm{O}\right)$ and then cut equatorially. Sugar and acid extraction was done following the method of HAN (1986). Total soluble sugar content was determined using the anthrone sulfuric acid method as described by GONG et al. (2004). The reaction system contained $1 \mathrm{~mL}$ of fruit extract and $3 \mathrm{~mL}$ of anthrone sulfuric acid $(0.14 \mathrm{~g}$ of anthrone dissolved in $76 \mathrm{~mL}$ of conc. $\mathrm{H}_{2} \mathrm{SO}_{4}$ and $30 \mathrm{~mL}$ of $\mathrm{dH}_{2} \mathrm{O}$ ). Titratable acidity of the fruit extract was determined by titration with $0.1 \mathrm{M} \mathrm{NaOH}$ (endpoint $\mathrm{pH}$ 8.1) and the results were converted to citric acid concentrations in fruit. 


\section{IDH and ACO activity assays}

The extraction of IDH and ACO was done according to a modification of the method of SINGH et al. (2005). Briefly, the sample fruits were cut vertically into four sections along the central core as symmetrical axis. Then, $3 \mathrm{~g}$ of flesh fruit was taken from two of the four symmetrical sections and mixed in a clean mortar containing $2 \mathrm{~mL}$ of $0.2 \mathrm{M}$ Tris $\cdot \mathrm{HCl}$ extraction buffer ( $\mathrm{pH} 8.2$; containing $0.6 \mathrm{M}$ sucrose, $10 \mathrm{mM}$ erythorbic acid, and $0.1 \%$ Triton X-100). The composite samples were homogenized on ice $(2 \%$ PVPP was added to the homogenates of young fruits before days 90 after full bloom) and then centrifuged at $4,000 \times g$ for $15 \mathrm{~min}$ at $4^{\circ} \mathrm{C}$. After the supernatant was discarded, the precipitate was re-dissolved in 2 $\mathrm{mL}$ of extraction buffer and used for enzyme activity assays of IDH and cytosolic ACO.

For IDH activity assay, $1 \mathrm{~mL}$ reaction system containing $40 \mathrm{mM}$ HEPES buffer ( $\mathrm{pH} 8.2), 800$ $\mu \mathrm{M} N A D$, and $200 \mu \mathrm{M} \mathrm{MnSO}_{4}$ was used, and the reaction was initialized with $2 \mathrm{mM}$ isocitric acid. For cytosolic ACO activity assay, the enzyme extract was pre-incubated with an equal volume of $2 \mathrm{mM} \mathrm{GSH}$ for $1 \mathrm{~h}$. The $1 \mathrm{~mL}$ reaction system containing $40 \mathrm{mM}$ Tris $\cdot \mathrm{HCl}(\mathrm{pH} 7.5)$ and $100 \mu \mathrm{M} \mathrm{NaCl}$ was used, and the reaction was initialized with $200 \mu \mathrm{M}$ aconitate. Immediately after the substrates were added, the absorbance of the reactions was measured at $340 \mathrm{~nm}$ $\left(\mathrm{A}_{340}\right)$ on a spectrophotometer at a $30 \mathrm{~s}$ interval for $3 \mathrm{~min}$ and repeated for three times. One unit of the enzyme activity was defined as 0.01 change in the absorbance per minute and the enzyme activity was expressed as the unit enzyme activity per milligram of enzyme protein ( $\mathrm{U} \cdot \mathrm{mg}^{-1}$ Pro). The soluble protein content determined by Coomassie brilliant blue (CBB) staining with bovine serum albumin (BSA) was used as the standard (GONG et al., 2004; 2006).

\section{Analysis of SPS and SS activity}

The extraction of SPS and SS was done according to the method of GONG et al. (2004). Briefly, the fruits were cut vertically into four sections with the central core as the symmetrical axis. Then, 1-2 $g$ of fruit flesh was taken from two of the four symmetrical sections and mixed in a clean mortar containing a small amount of quartz sand particles and $10 \mathrm{~mL}$ of $200 \mathrm{mM}$ HEPES-NaOH extraction buffer (5 mM $\mathrm{MgCl}_{2}, 0.1 \% \beta$-mercaptoethanol, $0.05 \%$ Triton-X 100, 0.05\% BSA, 2\% PVPP, 1 mM EDTA, $1 \mathrm{mM}$ EGTA, $10 \mathrm{mM}$ sodium ascorbate, $10 \mathrm{mM}$ Cys$\mathrm{HCl}$, and $2 \%$ glycerol; $\mathrm{pH} 7.5$ ). The composite sample was homogenized for $5-10 \mathrm{~min}$ and then centrifuged at $15,000 \times \mathrm{g}$ for $30 \mathrm{~min}$ at $4^{\circ} \mathrm{C}$. The supernatant was collected and gradually added with solid $\left(\mathrm{NH}_{4}\right)_{2} \mathrm{SO}_{4}$ to $20 \%$ saturation level, then centrifuged at $15,000 \times g$ for $10 \mathrm{~min}$ at $4^{\circ} \mathrm{C}$. Thereafter, the supernatant was collected and gradually added with solid $\left(\mathrm{NH}_{4}\right)_{2} \mathrm{SO}_{4}$ to $80 \%$ saturation level. The mixture was allowed to sit for 20-30 min and then centrifuged at 15,000 $\times g$ for $30 \mathrm{~min}$. After the supernatant was discarded, the precipitate was re-dissolved in $20 \mathrm{mM}$ HEPES$\mathrm{NaOH}$ desalt buffer $\left(0.25 \mathrm{mM} \mathrm{MgCl}_{2}, 1 \mathrm{mM}\right.$ EDTA, $1 \mathrm{mM}$ EGTA, $0.01 \% \beta$-mercaptoethanol, $0.05 \%$ BSA, and $0.2 \%$ glycerol; $\mathrm{pH} 7.5$ ) and dialyzed in a dialysis bag for $16 \mathrm{~h}$. The desalted enzyme extract was used for enzyme activity assays of SPS and SS in the synthetic direction.

The activities of SPS and SS in the synthetic direction were assayed according to the methods of LOWELL et al. (1989) and HUBER et al. (1989). For SPS activity assay, the $70 \mu \mathrm{L}$ reaction system contained $50 \mathrm{mM}$ HEPES-NaOH buffer ( $\mathrm{pH} 7.5$ ), $15 \mathrm{mM} \mathrm{MgCl} 2,1 \mathrm{mM}$ EDTA, $5 \mathrm{mM} \mathrm{NaF}, 16 \mathrm{mM}$ UDP-glucose, 4 mM Fru 6-P, 20 mM Glc 6-P, and an appropriate amount of enzyme extract. For SS activity assay, the $70-\mu \mathrm{L}$ reaction system contained $80 \mathrm{mM}$ HEPES-NaOH buffer ( $\mathrm{pH} 8.5), 5 \mathrm{mM}$ $\mathrm{KCN}, 5 \mathrm{mM}$ NaF, $100 \mathrm{mM}$ levulose, $15 \mathrm{mM}$ UDPglucose, and an appropriate amount of enzyme extract. The reactions were incubated at $30^{\circ} \mathrm{C}$ for $30 \mathrm{~min}$ and then terminated by adding $70 \mu \mathrm{L}$ of $5 \mathrm{M}$ $\mathrm{NaOH}$ solution and heating in a boiling water bath for $10 \mathrm{~min}$. After cooling down, the reactions were added with $1 \mathrm{~mL}$ of $0.14 \%$ anthrone sulfuric acid and incubated at $40^{\circ} \mathrm{C}$ for $20 \mathrm{~min}$. Thereafter, the absorbance of the reactions was measured at 620 $\mathrm{nm}\left(\mathrm{A}_{620}\right)$ using a spectrophotometer. The control reactions were prepared without Fru 6-P and Glc 6-P (for SPS) or levulose (for SS in the synthetic direction). The enzyme activity was defined as the enzymatic production of sucrose from the substrates by unit protein per hour $\left(\mu \mathrm{mol} \cdot \mathrm{h}^{-1} \cdot \mathrm{g}^{-1}\right.$ Pro $)$. All measurements were done with three composite replicates of five fruits.

\section{Statistical analysis}

The results were expressed as means \pm standard errors of the means. Comparisons among different habitats or eco-regions were done by multiple comparison tests following analysis of variance (ANOVA) in SPSS15.0 software package. The differences were considered significant at a level of $P<0.05$. 


\section{RESULTS}

\section{The Changes of sugar-acid ratio of navel orange fruits from different eco-regions}

In the process of fruit development, the changes of sugar-acid ratio of navel orange fruits in different eco-regions were shown in Figure 1. It demonstrated that, there were small decreases in the sugar-acid ratio from 60 days to 75 days after full bloom, followed by a 15 -day plateau and a 45 -day slow increase in all eco-regions. However, at 60-135 days after full bloom, the sugar-acid ratio showed no significant variations between all eco-regions $(P>0.05)$. From 135 days after full bloom, the sugaracid ratio of the fruits began to increase significantly with fruit development $(P<0.01)$.

Furthermore, the changes of the sugar-acid ratio of fruits from three different eco-regions were compared. It suggested that the sugar-acid ratio of fruits substantially decreased from south to north $(P<0.01)$. That is, the fruits of south-subtropical eco-region (Hongge and Anning) had the highest sugar-acid ratio followed by the mid-subtropical eco-region (Changning and Jiang' an), and the lowest sugar-acid ratio was observed in fruits from the north mid-subtropical eco-regions (Mingshan and Ya'an). Statistical analysis showed that there were no significant differences in the sugar-acid ratio of fruits from different orchards in the same eco-region (Figure 2).

\section{The changes of IDH and ACO activities}

IDH and ACO are two important enzymes involved in sugar accumulation. Enzyme activity assay in Figure 3 showed that the IDH activity of navel oranges in different eco-regions first fluctuated at the early stage of fruit development (60-120 days after full bloom) and then substantially increased at 120-210 days after full bloom with fruit development. The IDH activity in fruits from different eco-regions had no significant differences before 120 days after full bloom, while it showed significance after 120 days $(P<0.01)$. Regarding different eco-regions, the IDH activity was the highest in fruits from south subtropics (Hongge and Anning) compared to that in other two ecoregions $(P<0.01)$, and the IDH activity of fruits from mid-subtropics (Changning and Jiang'an) was significantly higher than that of north mid-subtropics (Mingshan and Ya'an) $(P<0.05)$. Statistical analysis showed that there were no significant differences in the IDH activity of fruits from different orchards in the same eco-region $(P>0.05)$.

As shown in Figure 4, during the fruit development period, the cytosolic ACO activity of fruits from different eco-regions showed two evident increases at 60-90 days and 120-150 days and an obvious decrease at 180-210 days after full bloom in different eco-regions, respectively. However, the cytosolic ACO activity showed no significant differences in fruits among different eco-regions or between different orchards in the same eco-region $(P>0.05)$.

The results above suggested that cytosolic ACO activity of fruits showed little changes while the IDH activity of fruits showed significant changes in different eco-regions, indicating an important role of IDH in sugar accumulation during fruit development.

\section{The changes of SPS and SS activities}

Two enzymes, SPS and SS adjusted the organic acid cleavage, and potentially played a key role in regulating the sugar-acid ratio during fruit development. The observation suggested that the SPS activity first increased by approximately four times and then substantially decreased to the low level below the initial value after 150 days after full bloom $(P<0.05)$. However, there were minor variations in SPS activity among different eco-regions or between different orchards in the same eco-region $(P>0.05)$ (Figure 5).

The results in Figure 6 expressed that the changes of SS activity in the synthetic direction were relatively complex in navel oranges at different fruit development stages. Significant differences were observed in the SS activity of fruits among different eco-regions, especially from 105 days after full bloom $(P<0.01)$. Regarding the special variation, the SS activity of fruits in the synthetic direction was higher in south subtropics (Hongge and Anning) and mid-subtropics (Changning and Jiang'an) than that of north mid-subtropics (Mingshan and Ya'an) $(P<0.01)$. There was no significant difference in the activity of SS in the synthetic direction of fruits between south subtropics and mid-subtropics $(P>0.05)$. Additionally, no significant differences were observed in SS activity of fruits from different orchards in the same ecoregion $(P>0.05)$. It demonstrated that the key enzyme $\mathrm{SS}$ was involved in regulating the sugar-acid ratio in navel oranges, which provided guiding information for agriculture practice and food processing of navel oranges. 


\section{DISCUSSION}

Citrus fruit accumulate large amounts of sugars, mainly sucrose, glucose, and fructose during the development (TEWARI et al., 2008). Previously, our study demonstrated that the activities of SPS, SS in the synthetic direction, ACO and IDH were closely related to the sugar-acid ratio in navel oranges at fruit development stages (GONG et al., 2008). In the present study, we attempted to identify the key enzymes that control the fruit quality such as flavor quality in different eco-regions by evaluating the changes of sugar-acid ratio and relevant metabolizing enzyme activities in navel oranges from six representative habitats (orchards) in three ecoregions in Sichuan Province. This study demonstrated that the sugar-acid ratio in navel oranges had small fluctuations among different eco-regions at 135 days before full bloom and substantially increased to different extents. Furthermore, the sugar-acid ratio was generally higher in the south-subtropics than in the (north) mid-subtropics, suggesting that better flavor quality of fruits was obtained in a dry, hot climate. Results also confirmed that the sugar-acid ratio and the activities of SPS, SS in the synthetic direction, ACO and IDH substantially were changed with fruit development and eco-region types. This finding can be used for agricultural management of navel oranges that aims to improve the fruit quality.

Cytosolic ACO and SPS are known to respectively regulate organic acid cleavage and sugar accumulation in fruit at the development stages, further affecting the flavor quality (GONG et al., 2004). It is well established that SPS plays a pivotal role in sucrose synthesis (FOYER et al., 2003; STITT et al., 2002). The isomerization of citrate to isocitrate catalyzed by aconitase is a key step in acid metabolism. Inhibition of mitochondrial aconitase activity early in fruit development contributes to acid accumulation (DEGU et al., 2011). Despite the substantial changes in the sugar-acid ratio, it was observed that the activities of cytosolic ACO and SPS occurred at similar levels in fruits from different eco-regions. However, our previous study showed a strong correlation relationship between the sugar-acid ratio and the activities of four potentially key enzymes cytosolic ACO, SPS, SS and IDH in navel oranges (GONG et al., 2008). Thus, it was speculated that cytosolic ACO and SPS were not the main controlling factors of the sugar-acid ratio in navel oranges from different eco-regions, whereas SS and IDH played a key role in regulating the sugar-acid ratio of navel oranges at the fruit development stages. Further studies are needed to explore the exact regulatory function of cytosolic ACO and SPS in the flavor quality of navel orange fruits.

The accumulation of citric acid and its decline toward fruit maturation is typical of citrus fruit. IDH is involved in citrate metabolism and its activity keeps increasing throughout fruit development (SADKA et al., 2000). KUBO et al. (2002) reported that IDH was a key enzyme that limited organic acid accumulation in citrus fruits, and its primary function in citrus fruits at the development stages was to cleave organic acids, similar to cytosolic ACO. As for the SS, a number of studies have demonstrated that its activity is positively correlated with the degree of sucrose accumulation, and that it is a biochemical determinant of sink strength in fruit (LI et al., 2012; ALBACETE et al., 2014; HOLLAND et al., 2005). Thus, the SS in turn plays a regulatory role in importing sucrose substrate into the fruit. Because IDH and SS in the synthetic direction can respectively regulate the sugar-acid ratio of fruits by accelerating the organic acid metabolism and sugar accumulation, it is understandable that both enzymes play a positive role in the flavor quality of navel oranges (HOLLAND et al., 2005). In this study, we found that the changes of the activity of IDH and SS in the synthetic direction among different eco-regions generally were corresponded to the changes of the sugar-acid ratio of the fruits, suggesting the important roles of IDH and SS in the synthetic direction in regulating the flavor quality of navel orange fruits. It also indicated that the enzyme activities of IDH and SS in the synthetic direction were likely attributed to regional climatic conditions and/or other eco-factors (e.g., vegetation and soil type), which led to the differences in sugar and organic acid contents as reflected by the changes in sugar-acid ratio. 
TABLE 1- Main eco-factors of the three representative eco-regions in Sichuan Province.

\begin{tabular}{|c|c|c|c|c|c|c|c|c|c|}
\hline Areas & $\begin{array}{c}\text { Annual } \\
\text { temperature } \\
\left({ }^{\circ} \mathrm{C}\right)\end{array}$ & $\begin{array}{c}\text { Annual } \\
\text { rainfall } \\
(\mathbf{m m})\end{array}$ & $\begin{array}{c}\text { Annual } \\
\text { light } \\
\text { hours } \\
\text { (h) }\end{array}$ & $\begin{array}{c}\geq 10^{\circ} \mathrm{C} \\
\text { annual } \\
\text { ccumulated } \\
\left({ }^{\circ} \mathrm{C}\right) \\
\end{array}$ & $\begin{array}{c}\text { Annual } \\
\text { relative } \\
\text { humidity } \\
(\%)\end{array}$ & $\begin{array}{l}\text { Soil } \\
\text { type }\end{array}$ & $\begin{array}{l}\text { Altitude } \\
\text { (m) }\end{array}$ & Vegetation & Eco-region \\
\hline Ya'an & 16.5 & 1439.6 & 1039.6 & 5026 & 80 & $\begin{array}{l}\text { Yellow } \\
\text { soil }\end{array}$ & 629 & Lauriliguosa & $\begin{array}{l}\text { North mid- } \\
\text { subtropics }\end{array}$ \\
\hline Mingshan & 16.9 & 1245.1 & 1040 & 5181 & 81.5 & $\begin{array}{c}\text { Yellow } \\
\text { soil }\end{array}$ & 692 & Lauriliguosa & $\begin{array}{l}\text { North mid- } \\
\text { subtropics }\end{array}$ \\
\hline Changning & 18.7 & 942.1 & 1295 & 6083.1 & 83 & $\begin{array}{c}\text { Yellow } \\
\text { soil }\end{array}$ & 650 & Lauriliguosa & $\begin{array}{c}\text { Mid- } \\
\text { subtropics }\end{array}$ \\
\hline Jiang'an & 18.8 & 968.5 & 1386 & 6143.8 & 83 & $\begin{array}{c}\text { Yellow } \\
\text { soil }\end{array}$ & 315 & Lauriliguosa & $\begin{array}{c}\text { Mid- } \\
\text { subtropics }\end{array}$ \\
\hline Hongge & 19.1 & 743.8 & 2358.3 & 6932 & 68 & $\begin{array}{c}\text { Latosolic } \\
\text { red soil }\end{array}$ & 1446 & $\begin{array}{l}\text { Savanna-like } \\
\text { vegetation }\end{array}$ & $\begin{array}{c}\text { South } \\
\text { subtropics }\end{array}$ \\
\hline Anning & 19.4 & 757.4 & 2361.5 & 7069 & 71 & $\begin{array}{c}\text { Latosolic } \\
\text { red soil }\end{array}$ & 1057 & $\begin{array}{l}\text { Savanna-like } \\
\text { vegetation }\end{array}$ & $\begin{array}{c}\text { South } \\
\text { subtropics }\end{array}$ \\
\hline
\end{tabular}

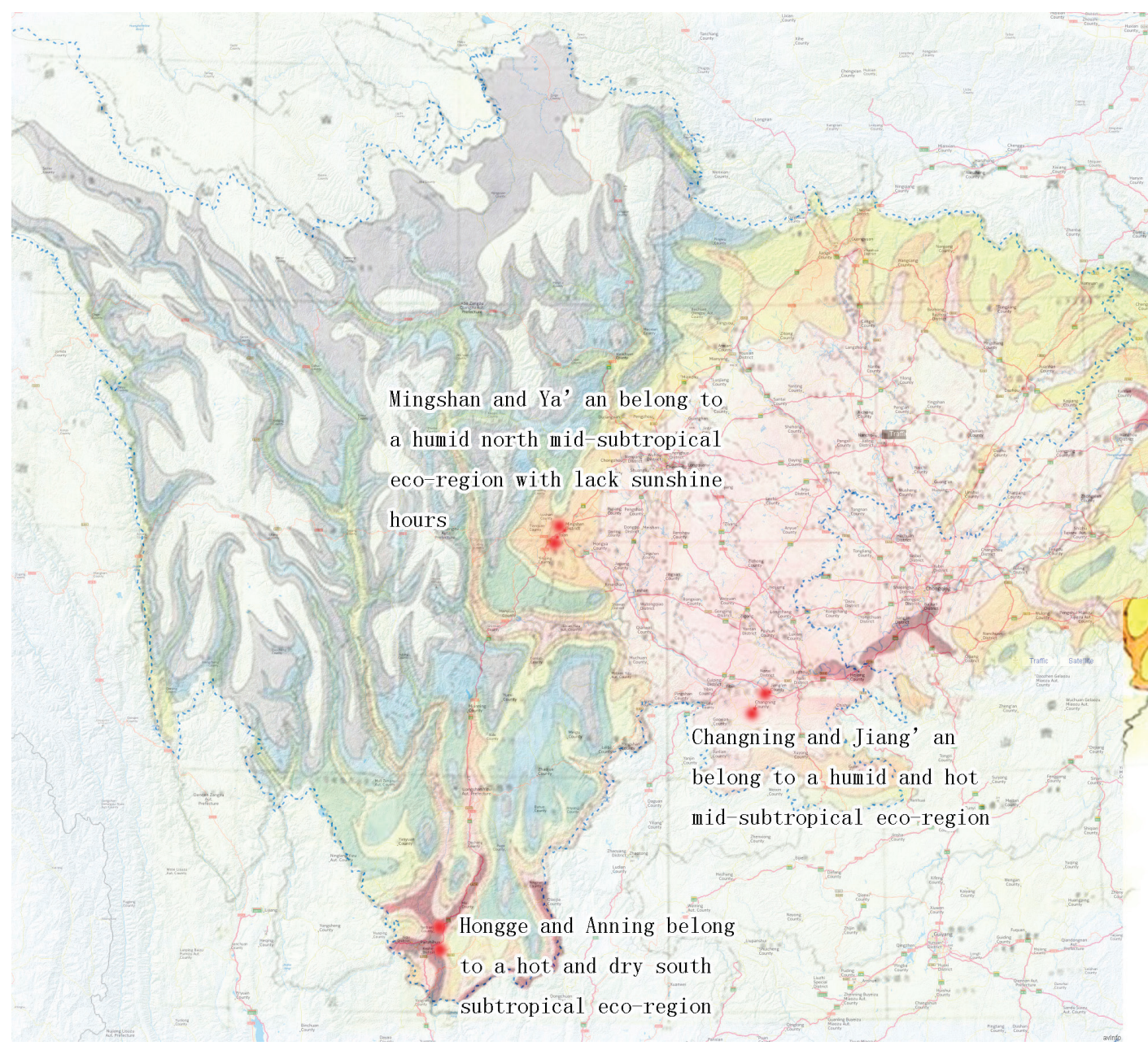

FIGURE 1 - A map of the country with the three eco-regions of Sichuan. 


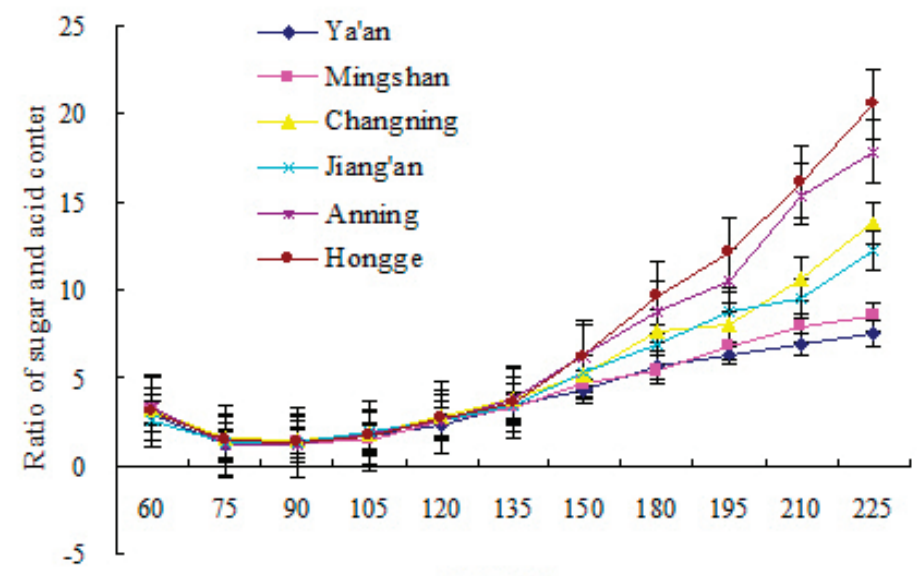

$\operatorname{DAFB}(\mathrm{d})$

FIGURE 2 -Changes in the sugar-acid ratio of navel orange during fruit development in different eco-regions.

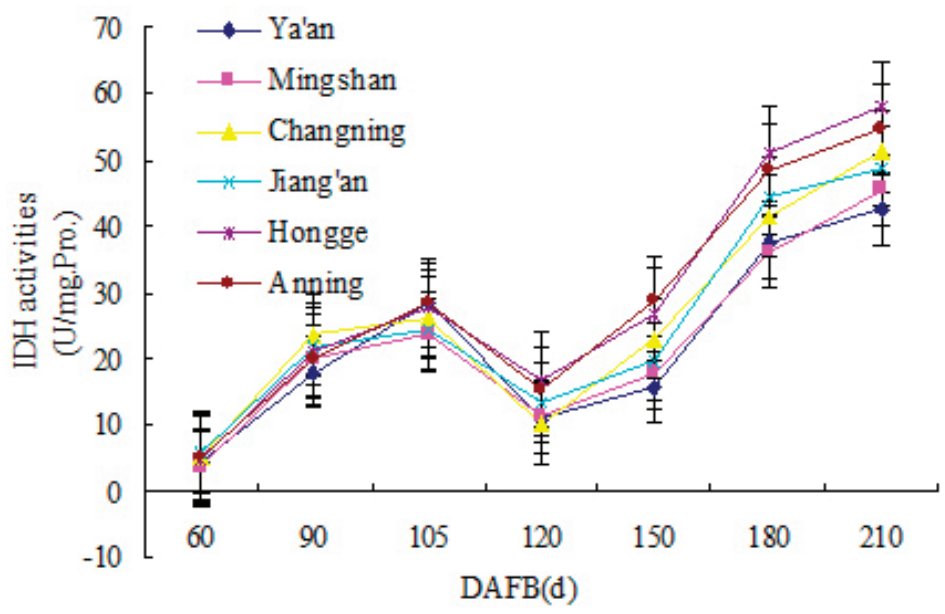

FIGURE 3 - Changes in isocitrate dehydrogenase (IDH) activity of navel orange during fruit development in different eco-regions.

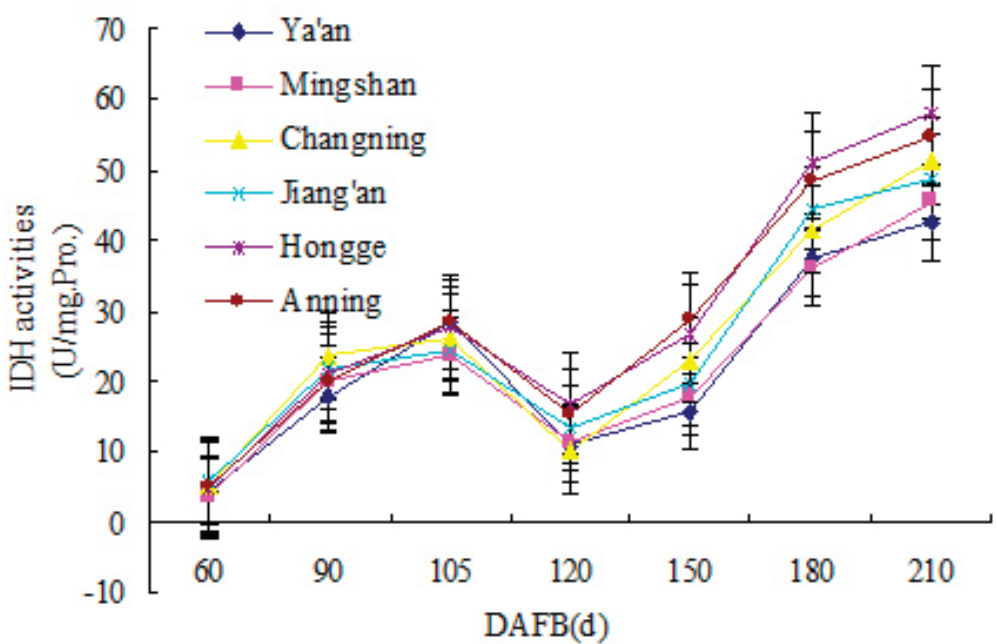

FIGURE 4 - Changes in cytosolic cio-aconitase (ACO) activity of navel orange during fruit development in different eco-regions. 


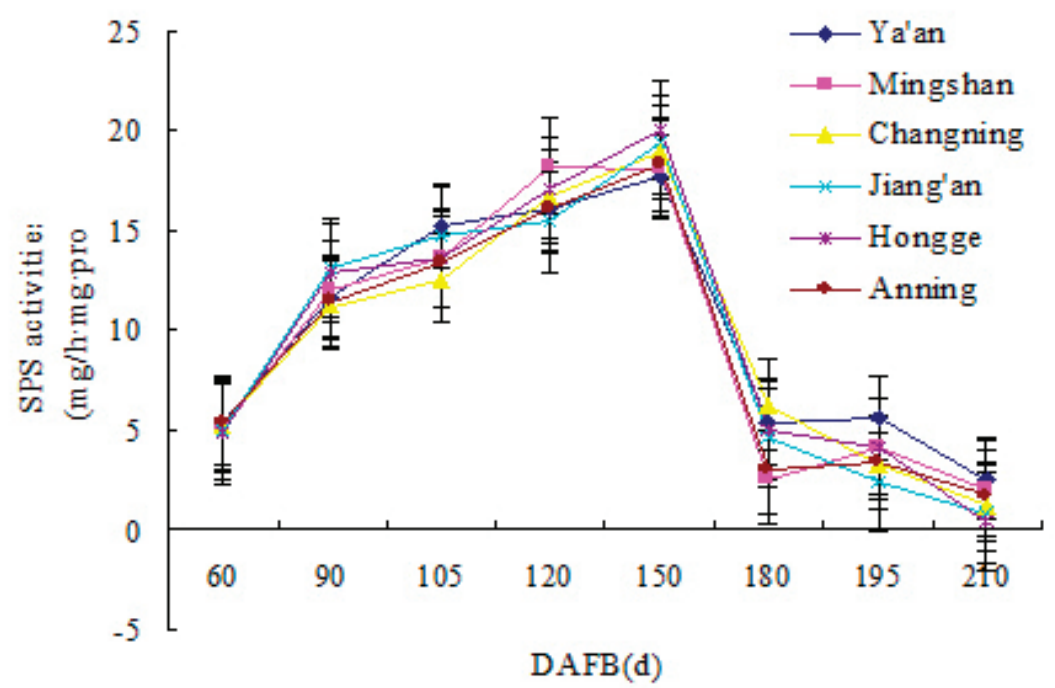

FIGURE 5 - Changes in sucrose phosphate synthase (SPS) activity of navel orange during fruit development in different eco-regions.

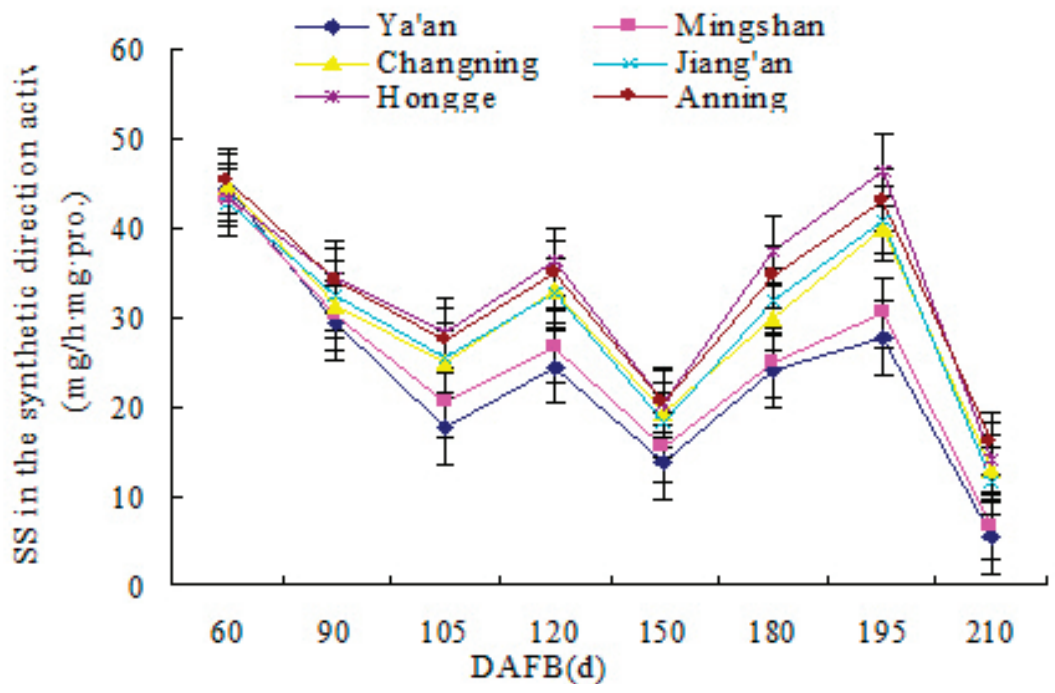

FIGURE 6 - Changes in the activity of sucrose synthase (SS) in the synthetic direction of navel orange during fruit development in different eco-regions.

\section{CONCLUSIONS}

In summary, this study demonstrated that IDH and SS in the synthetic direction were the key enzymes that control the sugar-acid ratio in navel oranges from different eco-regions in Sichuan Province, China, which would be helpful for relevant agricultural practice, food processing, and quality testing. Moreover, this study was limited and further studies need to be conducted to explore the decisive eco-factors of these enzymes and detailed mechanism of relevant enzymatic reactions for longer times.

\section{ACKNOWLEDGEMENTS}

This study was financially supported by the Sichuan Agricultural University and the Education Department of Sichuan Province (No. 2009ZA071). 


\section{REFERENCES}

ALBACETE, A.; CANTERO-NAVARRO, E.; BALIBREA, M.E.; GROßKINSKY, D.K.; DE LA CRUZ GONZÁLEZ, M.; MARTÍNEZ-ANDÚJAR, C.; SMIGOCKI, A.C.; ROITSCH, T.; PÉREZALFOCEA, F. Hormonal and metabolic regulation of tomato fruit sink activity and yield under salinity. Journal of Experimental Botany, Lancaster, v. 65, p.6081-6095, 2014.

ALBERTINI, M.V.; CARCOUET, E.; PAILLY, O.; GAMBOTTI, C.; LURO, F.; BERTI, L. Changes in organic acids and sugars during early stages of development of acidic and acidless citrus fruit. Journal of Agricultural and Food Chemistry, Easton, v.54, p.8335-8339, 2006.

BAO, J.; XIA, R.; DENG, X.; PENG, S.; LIU, Y.; MA, X.; ZHANG, H. The quality evaluation factors selection of Newhall orange by the principal component analysis. Journal of Hua Zhong Agriculture, Wuhan, v.23, p.663-666, 2004.

DARBYSHIRE, R.; WEBB, L.; GOODWIN, I.; BARLOW, E.W. Challenges in predicting climate change impacts on pome fruit phenology. International Journal of Biometeorology, Heidelberg, v.58, p.1119-1133, 2014.

DEGU, A.; HATEW, B.; NUNES-NESI, A.; SHLIZERMAN, L.; ZUR, N.; KATZ, E.; FERNIE, A.R.; BLUMWALD, E.; SADKA, A. Inhibition of aconitase in citrus fruit callus results in a metabolic shift towards amino acid biosynthesis. Planta, Berlin, v.234, p.501-513, 2011.

FOYER, C.H.; PERRY, M.; NOCTOR, G. Markers and signals associated with nitrogen metabolism in higher plants. Journal of Experimental Botany, Lancaster, v.54, p.585-593, 2003.

GONG, R.G.; LV, X.L.; ZHANG, G.L. Study on the ratio of sugar and acid content and its related metabolizing enzymes in Robertson navel orange during development of fruit. Journal Northern Horticulture, Haerbin, v.9, p.22-24, 2008.

GONG, R.G.; LV, X.L.; ZHANG, G.L.; ZENG, X.L.; LUO, N.; HU, Q. Study on the organic acidmetabolizing enzymes in Robertson navel orange during the fruit development. Journal of Sichuan Agricultural University, Ya'an, v.24, p.402-404, 2006.
GONG, R.G.; ZHANG, G.L.; LV, X.L.; ZENG, X.L.; LUO, L.; HU, Q. Study on the sucrose-metabolizing enzymes in navel orange fruit from different habitats. Acta Horticulturae Sinica, Beijing, v.34, n.6, p.719$722,2004$.

HAN, Y.S. Experimental guide of food chemistry. Beijing: China Agricultural University Press, 1986. p.89-90.

HASHIZUME, H.; TANASE, K.; SHIRATAKE, K.; MORI, H.; YAMAKI, S. Purification and characterization of two soluble acid invertase isozymes from Japanese pear fruit. Phytochemistry, New York, v.63, p.125-129, 2003.

HOLLAND, N.; MENEZES, H.C.; LAFUENTE, M.T. Carbohydrate metabolism as related to high-temperature conditioning and peel disorders occurring during storage of citrus fruit. Journal of Agricultural and Food Chemistry, Easton, v.53, p.8790-8796, 2005.

HUBER, J.L.; HUBER, S.C.; NIELSON, T.H. Protein phosphorylation as a mechanism for the regulation of spinach leaf sucrose-phosphate synthase activity. Archives of Biochemistry and Biophysics, Amsterdam, v.270, p.681-690, 1989.

KELEBEK, H. ; SELLI, S. Determination of volatile, phenolic, organic acid and sugar components in a Turkish cv. Dortyol (Citrus sinensis L. Osbeck) orange juice. Journal of the Science of Food and Agriculture, Chichester, v.91, p.1855-1862, 2011.

KUBO, T.; KIHARA, T.; HIRABAYASHI, T. The effect of spraying lead arsenateon citrate accumulation and the related enzyme activities in the juice saces of Citrus natsudaidai. Journal of the Japanese Society for Horticultural Science, Tokyo, v.71, p.305-310, 2002.

LI, M.; FENG, F.; CHENG, L. Expression patterns of genes involved in sugar metabolism and accumulation during apple fruit development. PLoS One, San Francisco, v.7, p.e33.055, 2012.

LIN, B. Effecting of spent mushroom substrates (SMS) and biogas residue on improving navel orange production and its fruit quality. Fujian Journal of Agricultural Science, Suzhou, v.3, p.293-295, 2006. 
LOWELL, C.A.; TOMLISON, P.T.; KOCH, K.E. Sucrose-metabolizing enzymes in transport tissues and adjacent sink structures in developing citrus fruit. Journal of Plant Physiology, Jena, v.90, p.1394-1402, 1989.

LUEDELING, E.; GIRVETZ, E.H.; SEMENOV, M.A.; BROWN, P.H. Climate change affects winter chill for temperate fruit and nut trees. PLoS One, San Francisco, v.6, p.e 20155, 2011.

LUO, A.C.; YANG, X.H.; DENG, Y.; LI, C.F.; XIANG, K.S.; LI, D.G. Organic acid concentrations and the relative enzymatic changes during the development of citrus fruit. Agricultural Science in China, Beijing, v.36, p.941-944, 2003.

SADKA, A.; DAHAN, E.; OR, E.; COHEN, L. $\mathrm{NADP}(+)$-isocitrate dehydrogenase gene expression and isozyme activity during citrus fruit development. Plant Science, Limerick, v.158, p.173-181, 2000.

SALAZAR-PARRA, C.; ARANJUELO, I.; PASCUAL, I.; ERICE, G.; SANZ-SÁEZ, A.; AGUIRREOLEA, J.; SÁNCHEZ-DÍAZ, M.; IRIGOYEN, J.J.; ARAUS, J.L.; MORALES, F. Carbon balance, partitioning and photosynthetic acclimation in fruit-bearing grapevine (Vitis vinifera L. cv. Tempranillo) grown under simulated climate change (elevated $\mathrm{CO} 2$, elevated temperature and moderate drought) scenarios in temperature gradient greenhouses. Journal of Plant Physiology, Jena, v.174, p.97-109, 2015.

SINGH, R.; CHÉNIER, D.; BÉRIAULT, R.; MAILLOUX, R.; HAMEL, R.D.; APPANNA, V.D. Blue native polyacrylamide gel electrophoresis and the monitoring of malate- and oxaloacetateproducing enzymes. Journal of Biochemical and Biophysical Methods, Amsterdam, v.64, p.189-199, 2005.

SNYDER, S.M.; REBER, J.D.; FREEMAN, B.L.; ORGAD, K.; EGGETT, D.L.; PARKER, T.L. Controlling for sugar and ascorbic acid, a mixture of flavonoids matching navel oranges significantly increases human postprandial serum antioxidant capacity. Nutrition Research, Tarrytown, v.31, p.519-526, 2011.
STITT, M.; MÜLLER, C.; MATT, P.; GIBON, Y.; CARILLO, P.; MORCUENDE, R.; SCHEIBLE, W.R.; KRAPP, A. Steps towards an integrated view of nitrogen metabolism. Journal of Experimental Botany, Lancaster, v.53, p.959-970, 2002.

TEWARI, J.C.; DIXIT, V.; CHO, B.K.; MALIK, K.A. Determination of origin and sugars of citrus fruits using genetic algorithm, correspondence analysis and partial least square combined with fiber optic NIR spectroscopy. Spectrochimica Acta Part A-Molecular and Biomolecular Spectroscopy, Amsterdam, v.71, p.1119-1127, 2008.

XIAO, J.; YAN, X.; PENG, S.; DENG, X.; FANG, Y. Relationship between boron deficiency occurrence and annual changes in contents of boron and sugar of Newhall navel orange. Acta Horticulturae Sinica, Beijing, v.33, p.356-359, 2006.

YANG, Z.; WANG, T.; WANG, H.; HUANG, X.; QIN, Y.; HU, G. Patterns of enzyme activities and gene expressions in sucrose metabolism in relation to sugar accumulation and composition in the aril of Litchi chinensis Sonn. Journal of Plant Physiology, Jena, v.170, p.731-740, 2013.

ZHANG, X.M.; WANG, W.; DU, L.Q.; XIE, J.H.; YAO, Y.L.; SUN, G.M. Expression patterns, activities and carbohydrate-metabolizing regulation of sucrose phosphate synthase, sucrose synthase and neutral invertase in pineapple fruit during development and ripening. International Journal of Molecular Sciences, Basel, v.13, p.9460-9477, 2012. 